\title{
OLIVE EMBRYO DEVELOPMENT STAGE AND THE POSSIBILITY OF OBTAINING VIABLE SEEDLINGS
}

\author{
J. Liñán and A. Troncoso \\ Instituto de Recursos Naturales \\ y Agrobiología, CSIC, \\ Sevilla, Spain
}

\author{
H.F. Rapoport \\ Instituto de Agricultura \\ Sostenible, CSIC, \\ Córdoba, Spain
}

Keywords: olive, embryo development

\section{Abstract}

When 'Manzanillo' olive embryos were excised at successive dates and cultured on onethird strength Murashige-Skoog medium, three stages of differing growth potential were observed: 1) An initial stage in which no germination was obtained, 2) An intermediate 'critical' period in which germination and viability percentage increased according to date and 3) A final stage, from the time when the embryo reached full size, in which germination and viability were maximum. In the intermediate 'critical' period the seed had obtained its final length and the embryo was undergoing rapid expansive growth. Anatomical studies indicated the presence of the future root and shoot apices and welldefined provascular strands throughout this period. As time progressed, however, the embryo tissues seemed to acquire greater metabolic content and cytoplasmic integrity.

\section{Introduction}

Among the benefits of obtaining seedlings from excised developing embryos are the shortening of the reproductive cycle and the time necessary to obtain seedlings, the elimination of unnecessary maturation time and the circumvention of dormancy factors (Monnier, 1995). The reduction of these limitations in the olive in order to obtain viable seedlings more rapidly is highly desirable for olive breeding programs (Acebedo et al., 1997). It has been demonstrated that the excised olive embryo is capable of in vitro germination prior to full maturation and the adquisition of dormancy (Lagarda et al., 1983; Rugini, 1990; Voyiatzis and Pritsa, 1994; Acebedo et al., 1997). Furthermore the in vitro germination rate appears to be related to embryo development (Lagarda et al., 1983; Voyiatzis and Pritsa, 1994).

The objectives of this study were to germinate excised olive embryos in vitro and to determine the embryo developmental stage and characteristics necessary for obtaining viable seedlings.

\section{Materials and methods}

The plant material used was from 'Manzanilla de Sevilla' grown in Sevilla, Spain. Fruits were harvested at weekly intervals, the mesocarp (flesh) was removed and the stony endocarp was broken in order to remove the seed (Crisosto and Sutter, 1985; SotomayorLeón and Caballero, 1990). The seeds were sterilized with hypochlorite and the embryos excised under sterile conditions and planted individually in sealed sterile test tubes containing $10 \mathrm{ml}$ of culture medium (Acebedo, 1997). For the earliest dates, when the embryo was too small to isolate, the whole, sterilized seed was planted. A $1 / 3$ strength MS medium (Murashige and Skoog, 1962) was used. The culture tubes were placed in a growth chamber at $25 \pm 2^{\circ} \mathrm{C}$ with a 16 -h photoperiod $111 \mathrm{mE} \mathrm{m}^{-2} \mathrm{~s}^{-1}$.

Germination was assessed as elongation and opening of the root-hypocotyl axis and as greening of the cotyledons. Seedling formation was assessed as tap root development and elongation, shoot development and true leaf formation. 
For 1993 and 1994 embryos were excised and cultured at weekly intervals from 3 to 14 weeks after bloom. In 1995 embryos were excised and cultured based on both date ( 5 consecutive weeks June 21 -July 19) and size $(4-5.5,5.6-7.5,7.6-9.5$ and $>9.5 \mathrm{~mm}$ embryo length) and anatomical studies were performed to evaluate embryo development. For the anatomical studies standard paraffin techniques for optical microscopy (Jensen, 1962) were utilized and the sections were stained with safranin, crystal violet and light green (Gerlach, 1969).

\section{$\underline{\text { 3. Results }}$}

Embryo germination in vitro was significant from 12 weeks after flowering in 1993 (table 1) and 13 weeks after flowering in 1994 (table 2). At these times the embryos had achieved $6 \mathrm{~mm}$ length. Seedling formation, the continued growth after germination to form a viable seedling, was substantially lower than germination at the earlier dates and then increased (tables 1 and 2). When embryos were tested taking into account both age and size, both of these factors had a favorable influence on in vitro germination (table 3 ).

The anatomical studies revealed that at all dates on which germination was achieved basic tissues which might enhance germination and future survival were present. These tissues were the provascular tissue, the shoot apex and the root apex. The staining of the cytoplasm and cellular contents of the older and larger embryos, however, was much more intense and complex than that observed in the younger and smaller embryos. Additionally, the cells of the older and larger embryos appeared fuller and less wrinkled.

\section{Conclusions}

In vitro germination of olive embryos depends on both date and size (table 1, 2, 3). These results support those of previous studies (Lagarda et al., 1983; Rugini, 1990; Voyiatzis and Pritsa, 1994). While obtaining viable seedlings depends on the same factors, the viable seedling success rate tends to be lower than that for germination, especially at the earlier dates (table 1,2 ). The characteristics assocciated with obtaining a high level of viable seedlings may be summarized as: The fruit and seed have reached final size; the pit (endocarp) has hardened, the endosperm has hardened, and the embryo has formed its mature structure consisting of cotyledons and root-hypocotyl axis and reached a minimum length of $6 \mathrm{~mm}$.

Anatomically the capacity of developing olive embryos to germinate in vitro seems to be related to a greater metabolic content and cytoplasmic integrity. The formation of anatomical structures such as provascular tissues, shoot apex and root apex occurred at all dates examined and did not seem to limit the germination capacity.

\section{$\underline{\text { References }}$}

Acebedo, M.M., Lavee, S., Liñan, J., and Troncoso, A. 1997. In vitro germination of embryos for speeding up seedling development in olive breeding programmes. Scientia Horticulturae 69: 207-215.

Crisosto, C. H., and Sutter, E. G. 1985a. Role of the endocarp in 'Manzanillo' olive seed germination. Journal of the American Society for Horticultural Science 110: 50-52.

Gerlach, D. 1969. A rapid safranin-crystal violet-light green staining sequence for paraffin sections of plant materials. Stain Technology 44: 210.

Jensen, W.A. 1962. Botanical Histochemistry. W.H. Freeman and Co., San Francisco.

Lagarda, A., Martin, G.C., and Polito, V.S. 1983. Anatomical and morphological development of 'Manzanillo' olive seed in relation to germination. Journal of the American Society for Horticultural Science 108: 741-743.

Monnier 1995. Culture of zygotic embryos. In "In Vitro Embryogenesis in Plants" (T.A. Thorpe, ed.), Vol. 20, pp. 117-153. Kluwer Academic Publishers, Dordrecht/Boston/London. 
Rugini, E. 1990. In vitro culture of the olive: an overview of the present scientific status. Acta Hort. 286: 93-96.

Sotomayor-León, E. M., and Caballero, J. M. 1990. An easy method of breaking olive stone to remove mechanical dormancy. Acta Hort. 286: 113-116.

Voyiatzis, D. G., and Pritsa, T. 1994. The onset and disappearance of relative dormancy of olive emryos as affected by age. Acta Hort. 356: 148-151.

Table 1. In vitro germination and seedling formation obtained from olive embryos at different times after bloom. (1993).

\begin{tabular}{ccccccc}
\hline $\begin{array}{c}\text { Sample } \\
\text { Date }\end{array}$ & $\begin{array}{c}\text { weeks after } \\
\text { bloom }\end{array}$ & $\begin{array}{c}\text { Fruit diameter } \\
(\mathrm{mm})\end{array}$ & $\begin{array}{c}\text { Seed length } \\
(\mathrm{mm})\end{array}$ & $\begin{array}{c}\text { Embryo length } \\
(\mathrm{mm})\end{array}$ & $\begin{array}{c}\text { Germin. } \\
\text { In vitro } \\
(\%)\end{array}$ & $\begin{array}{c}\text { Seedling } \\
\text { formn. }(\%)\end{array}$ \\
\hline 12 May & 3 & 3 & 0.7 & - & 0 & 0 \\
19 May & 4 & 3.7 & 1.8 & - & 0 & 0 \\
26 May & 5 & 4.8 & 2.9 & - & 0 & 0 \\
2 June & 6 & 6.4 & 5.3 & - & 0 & 0 \\
16 June & 8 & 9.0 & 7.7 & - & 0 & 0 \\
21 June & 9 & 9.8 & 8.0 & - & 0 & 0 \\
29 June & 10 & 12 & 9.2 & - & 0 & 0 \\
7 July & 11 & 12 & 9.2 & 3.5 & 0 & 0 \\
13 July & 12 & 12 & 9.2 & 6.8 & 62 & 25 \\
22 July & 13 & 12 & 9.2 & 7.9 & 80 & 80 \\
5 Aug. & 15 & 13 & 9.3 & 8.1 & 80 & 80 \\
\hline
\end{tabular}


Table 2. In vitro germination and seedling formation obtained from olive embryos at different times after bloom. (1994).

\begin{tabular}{ccccccc}
\hline $\begin{array}{c}\text { Sample } \\
\text { Date }\end{array}$ & $\begin{array}{c}\text { weeks after } \\
\text { bloom }\end{array}$ & $\begin{array}{c}\text { Fruit diameter } \\
(\mathrm{mm})\end{array}$ & $\begin{array}{c}\text { Seed length } \\
(\mathrm{mm})\end{array}$ & $\begin{array}{c}\text { Embryo length } \\
(\mathrm{mm})\end{array}$ & $\begin{array}{c}\text { Germin. } \\
\text { In vitro } \\
(\%)\end{array}$ & $\begin{array}{c}\text { Seedling } \\
\text { formn. }(\%)\end{array}$ \\
\hline 20 May & 4 & 5.0 & 3.4 & - & 0 & 0 \\
26 May & 5 & 6.8 & 4.3 & - & 0 & 0 \\
8 June & 7 & 9.6 & 8.0 & - & 0 & 0 \\
15 June & 8 & 10.9 & 8.0 & - & 0 & 0 \\
29 June & 10 & 11.2 & 8.8 & $1.0-2.0$ & 0 & 0 \\
5 July & 11 & - & 8.8 & 3.0 & 0 & 0 \\
12 July & 12 & - & 8.8 & 4.5 & 0 & 0 \\
19 July & 13 & - & 8.8 & 6.0 & 85 & 56 \\
26 July & 14 & - & 8.8 & 6.5 & 90 & 65 \\
2 Aug. & 15 & - & 8.8 & 7.0 & 100 & 75 \\
\hline
\end{tabular}

Table 3. Germination and seedling formation from excised olive embryos of different age and size. (1995).

\begin{tabular}{ccccccccc}
\hline \multicolumn{8}{c}{ Embryo size (length, mm) } \\
\hline Date & \multicolumn{2}{c}{ A (4-5.5) } & \multicolumn{2}{c}{ B (5.6-7.5) } & \multicolumn{2}{c}{ C (7.6-9.5) } & \multicolumn{2}{c}{ D (>9.5) } \\
\cline { 2 - 9 } & Germ. (\%) & $\begin{array}{c}\text { Seedling } \\
(\%)\end{array}$ & $\begin{array}{c}\text { Germ. } \\
(\%)\end{array}$ & $\begin{array}{c}\text { Seedling } \\
(\%)\end{array}$ & $\begin{array}{c}\text { Germ. } \\
(\%)\end{array}$ & $\begin{array}{c}\text { Seedling } \\
(\%)\end{array}$ & $\begin{array}{c}\text { Germ } \\
(\%)\end{array}$ & $\begin{array}{c}\text { Seedling } \\
(\%)\end{array}$ \\
\hline $21-6$ & 4 & 0 & 45 & 23 & - & - & - & - \\
$28-6$ & 25.4 & 17.6 & 48 & 24 & 72 & 50 & - & - \\
$5-7$ & 56.5 & 24 & 65 & 30 & 80 & 50 & - & - \\
$12-7$ & - & - & 83 & 74 & 83 & 83 & 83 & 83 \\
$19-7$ & - & - & 80 & 83 & 81 & 80 & 75 & 75 \\
\hline
\end{tabular}

